\title{
A missed diagnosis
}

\section{Atma Persad}

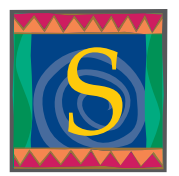

everal years ago, when I was a junior internal medicine resident in a large teaching hospital, I received a page to assess a patient who had been diagnosed with malaria and was running a fever. The nurse who paged me pointed out that he had been admitted under one of the most senior and well-respected internists on staff.

A third-year medical student was on call with me. It was an unusually busy night, and as we rushed to the patient's room, I attempted to exercise my fledgling teaching skills in a breathless discussion of the work-up of fever. Once we reached the patient, I was equally keen to demonstrate the fundamentals of history-taking. The medical student looked on, notebook in hand, furiously scribbling down the results of my Osler-like performance - until I came to the question, "And so, when were you diagnosed with malaria?"

An uncomfortable pause ensued. Looking blank, the already anxious man replied in a monotone, "I have malaria?"

Again another long silent pause filled the room as I performed a mental internal systems check on myself and wondered how I had got myself into this mess. Clearly, the patient had not yet been told he had malaria, and I had broken this bad news in a rushed and decidedly unempathetic fashion. My eager student-sidekick quizzically looked on, awaiting my response.

I proceeded with caution. Calmly, I asked the patient about the reason for his admission.

"I have asthma," he replied.

A quick glance at the nameplate at the head of the bed confirmed the diagnosis: right bed, wrong room.

I apologized to the patient, explained how the mix-up had occurred, and assured him that he did not have malaria. We excused ourselves and went in search of the real malarial patient.

If only that were the end of the story.

An hour later I received another page from the same medical floor. The nurse told me that the patient to whom I had mistakenly attributed malaria was very upset and wanted to see me. I sombrely returned to his room, where I

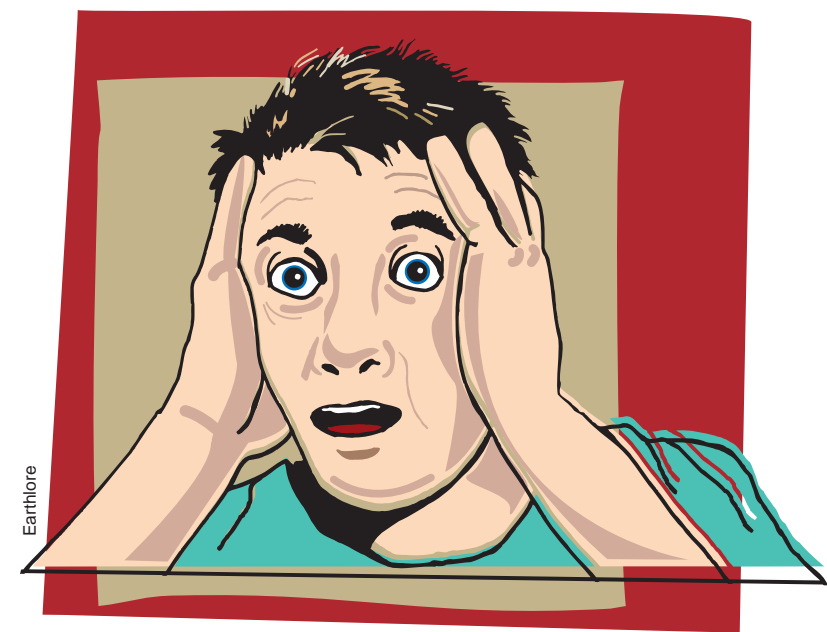

found him pacing beside his bed. Again I apologized, reassuring the patient that no change had been made in his care as a result of my error. I encouraged him to get some rest, and left the room.

Another hour passed before the next page came in. This time I was told that the anxious asthmatic had checked himself out against medical advice. Now I felt even more terrible and embarrassed.

I fretted about my unfortunate mistake for the rest of the night. How was I going to explain to the attending internist that I had caused a patient so much distress that he had left the hospital? Yet I knew there was no avoiding the truth.

The next morning I sheepishly approached the esteemed physician and confessed the case to him. I braced myself for a lashing.

"Oh, don't worry about it," he affably replied. "That fellow also has an anxiety disorder; that's the third time he's left the hospital AMA this week."

Lessons learned: always identify your patient, and the truth will set you free.

Atma Persad is a family physician in Creston, BC. 